\title{
ANALISIS TINDAKAN INDISIPLINER KERJA PADA PEGAWAI PD. BPR BANK GRESIK
}

\author{
Karima Diva Rifada ${ }^{1}$, Maulidyah Amalina Rizqi2 \\ 1,2Program Studi Manajemen, Fakultas Ekonomi dan Bisnis, \\ Universitas Muhammadiyah Gresik, Gresik, Jawa Timur, Indonesia \\ karimarifada99@gmail.com ${ }^{1}$, maulidyah@umg.ac.id ${ }^{2}$
}

\begin{abstract}
Background - Discipline is certainly an absolute requirement for the progress of the company or the progress of each individual. Without discipline, it would be impossible for all targets to be achieved properly, but at PD. BPR Bank Gresik there are employees who take disciplinary actions.

Objective - To analyze the crimes committed by employees as well as the efforts made by PD. BPR Bank Gresik in improving employee discipline.

Design/Methodology/Approach - This research is a type of qualitative research.

Findings - The cause of disciplinary action information about weather conditions, interests, time scheduling and family conditions. The cause of disciplinary action by leaving early is unexpected conditions and needs for family needs, employees who do not use shoes when working hours are still ongoing due to weather conditions, healthy conditions, while employees who do not use ID cards are because employees think that the use of ID cards is only used when there is a meeting outside the office

Research implications - Research contributes to minimizing individual action

Research limitations - This research is expected to better prepare themselves in the process of retrieval, study data and everything else and further researchers are expected to be able to carry out deeper research with different methods related to Disciplinary Action.
\end{abstract}

Keywords: : discipline, disciplinary efforts, indiscipline

\begin{abstract}
Abstrak
Latar Belakang - Kedisiplinan tentu menjadi syarat yang mutlak untuk kemajuan perusahaan ataupun kemajuan bagi personal masing-masing. Tanpa adanya kedisiplinan tentu mustahil segala target dapat tercapai dengan baik, akan tetapi di PD. BPR Bank Gresik terdapat adanya pegawai yang melakukan tindakan indisipliner.

Tujuan - Untuk menganalisis penyebab tindakan indisipliner kerja yang dilakukan pegawai serta upaya- upaya yang dilakukan PD. BPR Bank Gresik dalam meningkat kedisplinan pegawai.

Desain / metodologi / pendekatan - Penelitian ini merupakan jenis penelitian kualitatif.

Temuan - Penyebab tindakan indisipliner kerja mengenai keterlambatan adanya kondisi cuaca, kepentingan keluarga, penjadwalan waktu dan kondisi keluarga. Penyebab tindakan indisipliner dengan pulang cepat kondisi yang sifatnya tidak terduga dan adanya keperluan keluarga, pegawai yang tidak menggunakan sepatu ketika jam kerja masih berlangsung dikarenakan karena kondisi cuaca, kondisi sehatan, keperluan beribadah sedangkan untuk pegawai yang tidak menggunakan ID Card dikarenakan pegawai beranggapan bahwa pengguanaan ID Card hanya digunakan ketika ada acara pertemuan diluar kantor.

Implikasi penelitian - Penelitian berkontribusi untuk meminimalisir tindakan indispliner.
\end{abstract}

http://dx.doi.org/10.30587/mahasiswamanajemen.v2i01.2360

Program Studi Manajemen Universitas Muhammadiyah Gresik Jawa Timur Indonesia 
Batasan penelitian - Penelitian ini diharapkan lebih mempersiapkan diri dalam proses pengambilan, pengumpulan data dan segala sesuatunya dan peneliti selanjutnya diharapkan dapat melakukan penelitian lebih dalam denganmetode yang berbedaterkait dengan Tindakan Indisipliner Kerja.

Kata kunci : Disiplin, Upaya Kedisiplinan, Indisipliner

\section{PENDAHULUAN}

Kunci keberhasilan dari suatu intansi atau perusahaan yaitu pada sumber daya manusia, sumber daya manusia yang mampu menyelesaikan tanggung jawabnya dengan baik. Salah satu faktor yang sangat berpengaruh dalam sumber daya manusia adalah faktor kedisplinan. Dalam suatu organisasi kedisplinan sangat diutamakan, dimana semua karyawan harus mematuhi peraturan yang sudah ditetapkan oleh perusahaan. Menurut Simamora (2018: 610) disiplin kerja merupakan bentuk pengendalian diri karyawan dan pelaksanaan yang teratur yang menunjukan kesungguhan tim kerja didalam sebuah organisasi. Disiplin kerja akan menjamin terpliharanya tata tertib dan kelancaran pelaksanaan tugas, sehingga diperoleh hasil yang maksimal.

Kedisplinan merupakan bagian yang paling penting dari fungsi dari manajemen sumber daya manusia karena dengan adanya kedisplinan tujuan yang diharapkan maka akan mudah terwujud. Kedisiplinan tentu menjadi syarat yang mutlak untuk kemajuan perusahaan ataupun kemajuan bagi personal masing-masing. Tanpa adanya kedisiplinan tentu mustahil segala target dapat tercapai dengan baik. Menurut Singodimedjo(dalam Sutrisno 2017:86) disiplin karyawan yang baik akan mempercepat tujuan perusahaan, sedangkan disiplin yang merosot akan menjadi penghalang dan memperlambat pencapaian tujuan perusahaan.

PD. BPR Bank Gresik merupakan bank milik pemerintah kabupaten Gresik yang bergerak dibidang lembaga keuangan (Perbankan) dan memiliki komitmen untuk memberikan pelayanan yang terbaik kepada masyarakat. Pelayanan yang baik tentu didukung dengan kinerja stakeholder yang baik juga, khususnya dalam hal kedisplinan. Akan tetapi, komitmen dari PD. BPR Bank Gresik untuk memberikan pelayanan yang baik kepada masyarakat tidak didukung dengan kinerja beberapa stakeholder yang ada didalamnya khususnya dalam hal kedisplinan. Hal ini terjadi adanya beberapa pegawai 
yang melakukan tindakan indisipliner dengan melanggar peraturan yang sudah ditetapkan perusahaan.

Menurut KBBI (Kamus Besar Bahasa Indonesia), Indisipliner adalah tidak patuh kepada aturan, melanggar disiplin kerja. Pegawai melakukan tindakan indisipliner dengan datang terlambat ketika masuk kerja dan pulang cepat lebih awal dari waktu yang sudah ditetapkan sehingga dapat terjadinya penumpukan tugas. Pegawai juga memiliki etika berpakaian yang kurang baik, seperti sering memakai sandal ketika jam kerja berlangsung dan tidak memakai ID card ketika bekerja. Hal ini dapat menghambat kemajuan perusahaan karena tidak sesuai dengan visi dan misi perusahaan yaitu “Menjadi Bank Terdepan, Tangguh dan Profesional, Berguna Bagi Masyarakat". Ukuran yang dipakai dalam menilai apakah pegawai tersebut disiplin atau tidak, dapat terlihat dari ketepatan waktu, etika dalam berpakaian dan kepatuhan atau taat pada peraturan yang sudah ditetapkan (Soedjono, 2016: 67). Adapun data tindakan indisipliner yang dilakukan pegawai di PD. BPR Bank Gresik sebagai berikut.

Tabel 1

Rekapitulasi Data

Tindakan Indisipliner Kerja Pegawai PD. BPR Bank Gresik Tiga bulan terakhir Tahun 2020

\begin{tabular}{|c|c|c|c|c|}
\hline Bulan & \multicolumn{2}{|c|}{ Tindakan Indisipliner } & \multirow{2}{*}{$\begin{array}{c}\text { Jumlah } \\
\text { Tindakan } \\
\text { Indisipliner }\end{array}$} & Total Rata-Rata Durasi \\
\cline { 2 - 3 } & Terlambat & Pulang Cepat & 5 Kali & 10 Menit \\
\hline Mei & 4 & 1 & 7 Kali & 45 Menit \\
\hline Juni & 6 & 1 & 36 Kali & 54 Menit \\
\hline Juli & 27 & 9 & & \\
\hline
\end{tabular}

Dalam sebuah aktivitas pekerjaan apapun, kedisiplinan menjadi tolak ukur utama dalam mencapai seluruh perencanaan yang telah disusun bersama. Kedisplinan menjadi syarat yang mutlak yang harus dipenuhi dalam rangka mewujudkan visi misi dan tujuan perusahaan (Hasibuan, 2018:194). Suatu perusahaan akan sangat membutuhkan ketaatan dari anggota-anggotanya untuk mematuhi peraturan dan ketentuan yang berlakudi perusahaan. Disiplin kerja pegawai sangat dibutuhkan, karena apa yang menjadi tujuan perusahaan akan sukar dicapai bila tidak ada disiplin kerja dari pegawainya. Disiplin yang baik mencerminkan besarnya rasa tanggung jawab seseorang terhadap tugas-tugas yang diberikan kepadanya. Hal ini akan mendorong gairah kerja, semangat kerja, dan terwujudnya tujuan perusahaan. 


\section{TINJAUAN PUSTAKA}

\section{Disiplin Kerja}

Disiplin merupakan suatu perilaku yang harus ditanamkan pada setiap individu didalam maupun diluar organisasi.Setiap individu harus mengikuti dan menaati segala peraturan yang berlaku yang telah disepakati bersama serta bersedia menerima segala konsekuensi apabila melanggar peraturan yang telah disepakati sebelumnya. Menurut Sutrisno (2017: 86) mendefinisikan disiplin adalah perilaku seseorang yang sesuai dengan peraturan, prosedur kerja yang ada atau disiplin adalah sikap, tingkah laku dan perbuatan yang sesuai dengan dengan peraturan dari organisasi baik tertulis maupun tidak tertulis. Dalam melakukan aktivitas didalam suatu intansi atau perusahaan, aturan tertulis maupun tidak tertulis diperlukan sebagai petunjuk kerja bagi karyawan sehingga dapat tercipta disiplin kerja yang baik.

\section{Faktor-faktor Disiplin Kerja}

Menurut Singodimedjo dalam Sutrisno, (2016:89) baik buruknya disiplin seseorang dalam bekerja tidak muncul begitu saja, melainkan terdapat adanya beberapa faktor yang mempengaruhi displin kerja pegawai yaitu :

1. Besar kecilnya kompensasi

Besar kecilnya kompensasi dapat mempengaruhi tegaknya disiplin, para karyawan akan mematuhi segala peraturan yang berlaku, apabila ia merasa mendapatkan jaminan jasa yang setimpal dengan balas jasa jerih payahnya yang telah dikonstribusikan kepada perusahaan.

2. Ada tidaknya keteladanan pimpinan dalam perusahaan

Keteladanan pemimpin sangat penting sekali dalam menegakkan kedisplinan pegawai, karena dalam lingkungan kerja semua pegawai akan selalu memperhatikan dan mengikuti bagaimana pemimpin menegakkan kedisplinan dalam dirinya sendiri.

3. Ada tidaknya aturan pasti yang dapat dijadikan pegangan

Pembinaan disiplin tidak akan dapat terlaksana dengan baik apabila didalam perusahaan tidak ada aturan tertulis yang pasti untuk dijadikan pegangan bersama. Disiplin tidak akan ditegakkan bila peraturan yang dibuat hanya berdasarkan instruksi lisan yang dapat berubah-ubah sesuai dengan kondisi dan situasi. 
4. Keberanian pimpinan dalam mengambil tindakan

Adanya tindakan terhadap karyawan yang melanggar peraturan, maka dalam hal ini pimpinan harus berani dalam mengambil tindakan yang sesuai dengan tingkat pelanggaran yang dibuatnya, sesuai dengan sanksi yang ada.

5. Ada tidaknya pengawasan pimpinan

Dalam setiap kegiatan yang dilakukan oleh perusahaan perlu adanya pengawasan yang akan mengarahkan para karyawan agar dapat melaksanakan pekerjaan dengan tepat dan sesuai dengan peraturan yang telah ditetapkan.

6. Ada tidaknya perhatian kepada para pegawai

Pegawai tidak hanya puas dengan adanya kompensasi yang tinggi, pekerjaan yang menantang, tetapi mereka juga masih membutuhkan perhatian yang besar dari pimpinanya sendiri.Keluhan dan kesulitan mereka ingin didengar, dan dicarikan jalan keluarnya.

7. Kurangnya kebiasaan-kebiasaan yang mendukung tegaknya kedisplinan

\section{Indisipliner Kerja}

Menurut KBBI (Kamus Besar Bahasa Indonesia), arti dari indisipliner adalah tidak patuh kepada aturan, melanggar disiplin kerja. Dalam hal ini indisipliner merupakan lawan dari kedisplinan berarti bentuk ketidakpatuhan.

\section{Bentuk Pelanggaran Disiplin Kerja}

Menurut Sentot (2015:185) dalam penegakan disiplin, bagian SDM harus berkonsultasi dengan dan manajer dari karyawan yang melanggar disiplin. Berikut ini bentuk-bentuk tindakan yang melanggar disiplin:

1. Keterlambatan

2. Ketidakhadiran

3. Bekerja dengan sembrono

4. Tidak mematuhi target kualitas dan jumlah

5. Bekerja dalam keadaan mabuk dan mengkonsumsi narkotika

6. Mencuri barang perusahaan

7. Menjalankan bisnis pribadi pada waktu jam kantor. 


\section{METODOLOGI PENELITIAN}

\section{Pendekatan Penelitian}

Pendekatan penelitian yang digunakan adalah kualitatif. Pendekatan penelitian kualitatif bertujuan untuk menjelaskan dan menguraikan secara sistematis terkait permasalahan yang akan diteliti yang selanjutnya ditarik kesimpulan.

\section{Lokasi dan Fokus Penelitian}

Lokasi penelitian dilakukan Jl. Basuki Rahmat No. 18, Bedilan, Kebungson, Kecamatan. Gresik, Kabupaten Gresik, Jawa Timur 61114. Penelitian ini difokuskan pada analisis tindakan indisipliner kerja pegawai PD. BPR Bank Gresik.

\section{Sumber Data dan Jenis Data}

Jenis data yang digunakan dalam penelitian ini adalah data primer. Sumber data primer dalam penelitian ini diperoleh secara langsung dari perusahaan melalui wawancara. Adapun wawancara dilakukan dengan Direktur Utama, Kepala bagian umum dan personalia dan Staff umum dan personalia.

\section{Teknik Pengumpulan Data}

Dalam penelitian ini pengumpulan data yaitu dengan menggunakan wawancara. Wawancara yang dilakukan secara semi terstruktur. Wawancara semi terstruktur sudah termasuk dalam kategori in-depth interview yang pelaksanaanya lebih bebas bila dibandingkan dengan wawancara terstruktur (Sugiyono, 2018:233). Tujuan dari wawancara jenis ini adalah untuk menemukan permasalahan secara lebih terbuka, dimana dalam penelitian ini pihak yang diajak wawancara diminta pendapat dan ideidenya. Dalam penelitian ini wawancara dilakukan dengan direktur utama, kepala umum dan personalia, serta staff umum dan personalia PD. BPR Bank Gresik.

\section{Unit Analisis}

Menurut Hamidi (2010: 75-76) Unit analisis adalah satuan yang diteliti bisa berupa individu, kelompok, organisasi, benda atau suatu peristiwa social seperti aktivitas individu atau kelompok sebagai subjek penelitian. Peneliti menentukan yang menjadi unit analisis yaitu pegawai PD. BPR Bank Gresik. 


\section{Informan}

Menurut Moleong (2018:132), informan adalah orang yang dimanfaatkan untuk memberikan informasi tentang situasi dan kondisi latar belakang penelitian, informan pada penelitian ini yaitu direktur utama, kepala bagian umum dan personalia dan staff umum dan personalia. Pada penelitian ini penentuan informan dipilih secara purposive sampling. Purposive sampling adalah teknik pengambilan sampel sumber data dengan pertimbangan tertentu. Alasan menggunakan purposive sampling adalah karena tidak semua sampel memiliki kriteria yang sesuai dengan fenomena yang diteliti (Sugiyono, 2018:216).

\section{Teknik Analisis Data}

Teknik analisis data dalam penelitian ini adalah analisis kualitatif deskriptif dengan mengolah data menggunakan model Miles And Huberman. Menurut Sugiyono(2018:246) mengemukakan bahwa aktivitas dalam analisis data kualitatif dilakukan secara interaktif berlangsung secara dan terus menerus sampai tuntas sehingga datanya jenuh. Aktivitas dalam analisis data yaitu reduksi data, penyajian data dan kesimpulan.

\section{Uji Keabsahan Data}

Teknik keabsahan data yang digunakan dalam penelitian ini yaitu dengan menggunakan teknik triangulasi sumber dan pengecekan anggota membercheck. Dalam penelitian ini teknik triangulasi dengan sumber yang dilakukan peneliti dilakukan dengan cara membandingkan hasil wawancara yang diperoleh dari masing - masing sumber sebagai pembanding untuk mengecek kebenaran informasi yang didapatkan kemudian data dideskripsikan, dikategorisasikan dan dikelompokkan mana yang persepinya sama dan mana yang berbeda sehingga didapat kesimpulan dan diminta kesepatakan membercheck.

\section{HASIL DAN PEMBAHASAN}

Disiplin kerja merupakan salah satu fungsi terpenting dalam perusahaan, karena tanpa adanya disiplin kerja maka tujuan akan sulit tercapai. Disiplin kerja yang dilakukan pegaawai PD. BPR Bank Gresik masih kurang maksimal dikarenakan masih ada beberapa pegawai yang datang telambat maupun pulang cepat dari waktu yang telah ditetapkan perusahaan. Dalam etika berpakaian masih ada beberapa pegawai yang 
menggunakan sandal ketika bekerja dan tidak menggunakan ID Card atau tanda pengenal ketika jam kerja masih langsung, hal ini dilakukan melainkan bukan tanpa sebab akan tetapi ada penyebab yang menjadikan pegawai melakukan tindakan tersebut.

Penyebab tindakan indisipliner yang dilakukan pegawai dengan datang terlambat dikarenakan kondisi yang tidak terduga, kondisi lalu lintas, jarak tempuh, penjadwalan waktu, kondisi cuaca, kondisi kesehatan dan adanya kepentingan keluarga. Kondisi yang tidak terduga pada waktu akan berangkat kerja menjadi alasan keterlambatan seoarang pegawai, adanya kondisi yang tidak terduga mengaharuskan agar pegawai diharuskan untuk tetap bisa mengantisipasi setiap aktivitasnya agar kondisi yang tidak terduga tidak akan terjadi. Penyebab keterlambatan lain karena kondisi lalu lintas misalnya karena adanya kemacetan, adanya kecelakaan yang tidak bisa dihindari.

Penyebab lain pegawai datang terlambat dikarenakan jarak tempuh, hal ini dijadikan sebuah alasan untuk pegawai datang terlambat, sebagai seorang pegawai yang bekerja di instansi diharuskan untuk bisa mengatur dengan baik. Penyebab pegawai yang terlambat dikarenakan kebiasaan buruknya, pegawai bangun kesiangan yang mengakibatkan pegawai tersebut datang terlambat, belum lagi masalah cuaca yang sedang tidak bisa diprediksi. Cuaca musim hujan sering kali terjadi di waktu sekarang, terkadang pegawai yang sedang perjalanan ke kantor terjebak hujan sehingga harus menunggu hujan sampai reda.

Kondisi cuaca yang tidak menentu juga menyebabkan kondisi kesehatan dari pegawai tersebut kurang baik. Penyebab dari keterlambatan yang dilakukan pegawai dikarenakan pegawai mempunyai kesehatan yang kurang baik karena tidak bisa menjaga pola makannya. Pegawai mengalami penyakit diare yang menyebabkan pegawai tersebut keluar masuk kamar mandi yang mengakibatkan terlambat datang. Urusan keluarga seringkali dijadikan alasan oleh pegawai. Pegawai PD. BPR Bank Gresik rata-rata adalah perempuan yang sudah mempunyai anak, sehingga sebagai wanita karir pegawai tersebut dituntut agar bisa untuk membagi waktunya dengan baik. Pada kenyataannya banyak pegawai masih belum bisa untuk membagi waktu untuk pekerjaan dan waktu untuk keluarganya, sehingga hal ini menyebabkan pegawai datang terlambat. 
Penyebab tindakan indisipliner lain yang dilakukan pegawai dengan pulang cepat dari waktu yang telah ditetapkan dikarenakan karena ada keperluan yang sifatnya mendadak. Pegawai yang bekerja di sebuah instansi dituntut untuk selalu profesional dalam bekerja, namun disisi lain ada keluarga yang harus diprioritaskan juga. Contohnya seperti pekerja yang memiliki orang tua dengan riwayat penyakit sehingga sering kambuh. Pegawai wanita yang sudah mempunyai anak tetap dituntut profesional dalam bekerja bahkan saat anaknya sedang sakit. Penyebab lain pegawai yang pulang cepat lebih awal dikarenakan ada urusan keluarga yang sifatnya tidak terduga dan mendadak seperti halnya kematian, tidak ada yang tau kapan seseorang akan tiada.

Munculnya tindakan indisipliner tentunya dari perilaku yang kurang baik yang sering dilakukan sehingga menimbulkan rasa kebiasaan, kebiasaan dari pegawai untuk selalu bisa untuk disiplin dalam hal apapun sangatlah susah apalagi mengenai etika berpakaian. Etika berpakaian pegawai Bank sangat penting untuk diprioritaskan karena kegiatannya yang menyangkut sebuah pelayanan dengan nasabah. Etika berpakaian yang dilakukan pegawai PD. BPR Bank Gresik masih kurang baik. Hal yamg seringkali terjadi yaitu pegawai menggunakan sandal disaat jam kerja masih belangsung. Penyebab dari pegawai yang menggunakan sandal dikarenakan pegawai tersebut terjebak hujan yang kemudian keadaan sepatunya basah.

Penyebab lain biasanya karena keadaan buang air yang mengharuskan pegawai tersebut memakai sandal. Setelah buang air biasanya pegawai enggan untuk mengganti sandalnya padahal diluar tunggu ada beberapa nasabah yang sedang menunggu, sehingga beberapa dari pegawai masih keluar masuk menggunakan sandal ketika jam kerja masih berlangung. Hal ini menunjukkan bahwa etika dari pegawai PD. BPR Bank Gresik dirasa kurang baik. Pemberian ID card atau kartu tanda pengenal diberikan fungsinya agar dipakai sebagai identitas pengenal. Banyak pegawai yang tidak menggunakan ID card dikarenakan pegawai hanya mementingkan memakai kartu ID card pada waktu pertemuan luar kantor dan mempertemui nasabah saja. Saat di dalam kantor pegawai enggan memakai kartu ID card karena lupa tidak membawa dan terkadang ID card dibawa tetapi hanya diletakkan ditempat meja.

Upaya-upaya yang dilakukan PD. BPR Bank Gresik dalam meningkatkan kedisplinan pegawai yaitu untuk pegawai yang melakukan tindakan indisipliner akan diberikan sanksi atau hukuman. Sanksi atau hukuman yang diberikan melalui dari 
teguran lisan, surat peringatan lisan, surat peringatan tertulis sampai sanksi administrative berupa pemotongan tunjangan. Dalam memperketat sistem absensi, PD. BPR Bank Gresik menggunakan sistem absensi berupa Finger print yaitu sistem absensi yang dilakukan dengan sidik jari dari pegawai. Untuk mengawasi segala aktivitas yang dilakukan pegawai mulai pegawai yang keluar dan pegawai yang masuk pihak PD. BPR Bank Gresik menerapkan penggunaan CCTV (Closed Cicuit Televeision) disetiap aktivitasnya. Untuk meningkatkan kedisiplinan pegawai pihak pimpinan dari PD. BPR Bank Gresik memberikan contoh keteladanan yang baik untuk para pegawainya. Bagi pegawai yang mempunyai kedisplinan yang baik maka akan ada imbalan ke insentifnya.

Pegawai yang dikenakan tindakan indisipliner tentu akan mendapatkan sanksi atau hukuman. Pegawai yang terlambat datang dan baru tiba dikantor apabila lebih dari 30 menit maka pegawai tersebut akan mendapatkan sanksi berupa pemotongan tunjangan. Apabila pegawai tersebut terlambat tanpa izin atau keterangan yang jelas selama 5 kali maka akan diberikan surat peringatan lisan dan apabila pegawai terlambat melebihi waktu 30 menit dan terlambat tanpa adanya izin selama 5 kali selama 3 bulan berturut-turut maka akan diberikan surat peringatan ke satu.

Pegawai yang melakukan tindakan indisipliner lain dengan pulang cepat sebelum waktunya maka akan diberikan sanksi atau hukuman. Apabila pegawai tersebut pulang dibawah jam 12.00, maka pegawai tersebut dianggap tidak masuk , maka konsekuensinya tunjangan dari pegawai akan dipotong. Kebijakan ini terapkan agar pegawai bisa untuk membiasakan diri mempunyai rasa kedisplinan yang baik sehingga dalam hal ini segala aktivitas yang dilakukan pegawai bisa teratur. Akan tetapi mengenai pegawai yang menggunakan sandal ketika bekerja dan pegawai tidak menggunakan Id card atau tidak menggunakan identitas pengenal maka pegawai tersebut hanya mendapatkan teguran secara lisan.

PD. BPR Bank Gresik dalam mengawasi aktivitas yang dilakukan pegawai hanya berandalkan Closed Cicuit Televeision (CCTV). CCTV digunakan untuk meningkatkan kedisplinan yang dilakukan pegawai dengan memantau dan mengawasi aktivitas pegawai. Penggunaan CCTV memudahkan pihak stakeholder yang ada didalam perusahaan akan mengetahui segala gerak-gerik perilaku yang dilakukan pegawainya. Upaya-upaya lain yang dilakukan pihak PD. BPR Bank Gresik untuk meningkatkan 
kedisplinan pegawai yaitu mengubah sistem absensi. Awalnya menggunakan sistem manual sehingga sering kali terjadi kecurangan, namun sekarang pihak PD. BPR Bank Gresik menetapkan sistem absen berupa sistem Finger print.

Sistem Finger print dilakukan dengan menggunakan sidik jari pegawai yang bisa dilakukan kapan saja meski pegawai tersebut datang terlambat maupun pulang cepat. Dalam menerapkan segala kebijakan atau peraturan yang sudah ditetapkan, pihak PD. BPR Bank Gresik melakukan pengamatan, menganalisa terlebih dahulu, salah satunya mengenai penyebab adanya beberapa pegawai yang melakukan tindakan indisipliner, setelah melakukan pengamatan kemudian dianalisa sehingga pihak PD. BPR Bank Gresik mempunyai standar-standar atau ukuran-ukuran yang sesuai mengenai peraturan yang dibuatnya, peraturan tersebut dalam bentuk SOP yang ada di SK direksi surat yang sudah ditetapkan oleh direksi.

\section{KESIMPULAN}

Berdasarkan hasil penelitian dan pembahasan yang telah dikemukakan dalam penelitian ini dapat diambil beberapa kesimpulan sebagai berikut :

1. Penyebab tindakan indisipliner kerja mengenai keterlambatan dikarenakan karena adanya kondisi yang tidak teduga, kondisi kesehatan, kondisi cuaca, kepentingan keluarga, penjadwalan waktu dan kondisi keluarga. Penyebab tindakan indisipliner dengan pulang cepat sebelum waktunya dikarenakan kondisi yang sifatnya tidak terduga dan adanya keperluan keluarga, sedangkan untuk pegawai yang tidak menggunakan sepatu ketika jam kerja masih berlangsung dikarenakan karena kondisi cuaca, kondisi sehatan, keperluan beribadah dan keperluan pribadi, sedangkan untuk pegawai yang tidak menggunakan ID Card dikarenakan pegawai beranggapan bahwa pengguanaan ID Card hanya digunakan ketika ada acara pertemuan diluar kantor namun selebihnya pegawai enggan untuk memakai dan meletakkan diatas meja sampai ketinggalan dirumah.

2. Upaya-upaya yang dilakukan PD. BPR Bank Gresik dalam meningkatkan kedisplinan pegawai dilakukan dengan berbagai macam cara mulai dari teguran secara lisan, surat peringatan lisan, surat peringatan tertulis sampai dengan sanksi administratif, pimpinan yang memberikan ketauladanan, menerapkan ketetapan sistem absensi Finger print dan penggunaan CCTV. 


\section{REKOMENDASI}

Penulis memberikan rekomendasi kepada peneliti selanjutnya yaitu peneliti selanjutnya diharapkan lebih mempersiapkan diri dalam proses pengambilan, pengumpulan data dan segala sesuatunya dan peneliti selanjutnya diharapkan dapat melakukan penelitian lebih dalam dengan metode yang berbedaterkait dengan Tindakan Indisipliner Kerja.

\section{DAFTAR PUSTAKA}

Hasibuan,Malayu S.P 2018. Manajemen Sumber Daya Manusia, PT Bumi Aksara: Jakarta.

Moleong, L.J. 2018.Metode Penelitian Kualitatif. PT.Remaja Rosdakarya: Bandung.

Simamora, Henry.2018. Manajemen Sumber Daya Manusia, STIEY: Yogyakarta.

Sugiyono.2018. Metode Penelitian Kuantitatif, Kualitatif, dan RED. Alfabeta:Bandung.

Sutrisno,Edy. 2017. Manajemen Sumber Daya Manusia. Cetakan kesepuluh. Pranada Media Group. Jakarta.

Taufik, Akbar. 2017. AnalisisDisiplin Kerja Kryawan Kontrak Pda PT. AT Indonesia di Karawang.. Jurnal Lentera Bisnis, Vol.6.No.1.

Wahjono, Sentot Imam. 2015. Manajemen Sumber Daya Manusia. Salemba Empat. Jakarta. 